\title{
The incidences of upper gastrointestinal and colorectal malignancies in Ağrı city of eastern Anatolia
}

\section{Doğu Anadolu'da bullunan Ağrı şehrindeki üist gastrointestinal ve kolorektal malignite insidansı}

\author{
Erkan Caglar ${ }^{1}$, Kadir Balaban ${ }^{2}$, Deniz Atasoy ${ }^{3}$, Aslı Sezgin Caglar ${ }^{4}$, Abdurrahman Akay
}

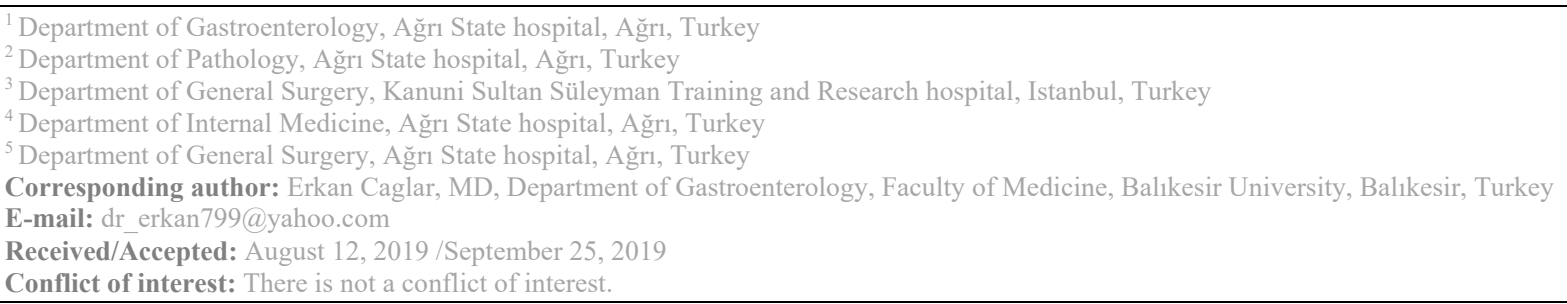

\section{SUMMARY}

Objective: Gastrointestinal tract malignancies comprise essential morbidity and mortality reasons in east Anatolia. The data regarding the incidences and clinical symptoms of these malignancies in this region are scarce.

Method: All endoscopic interventions and obtained biopsies between July 2014 and August 2015 were reviewed retrospectively. Ageadjusted and crude incidences were calculated according to the midpopulation number in 2014 given by the regional governorship.

Results: A total of 1176 endoscopic interventions (927 (78.8\%) upper endoscopy and 249 (21.2\%) colonoscopy) were performed within 12 months of time interval. As a result of these endoscopic interventions, 14 (19.1\%) esophageal cancers, 49 (67.1\%) gastric cancers, and $10(13.6 \%)$ colorectal cancers were diagnosed. Crude incidences per 100.000 individuals for esophageal cancer were 2.4 and 2.6, for gastric cancer were 9.1 and 8.3, and for colorectal cancer were 2.8 and 0.7 for men and women, respectively. Gender and ageadjusted esophageal cancer rates per 100.000 individuals for men between 30-34 years was 0.34 and for women between $40-44$ years was 3.03. While weight loss was more common in upper gastrointestinal malignancies $(49.2 \%$ vs. $10 \%, \mathrm{p}<0.001)$, anemia was more common in colorectal malignancies $(90 \%$ vs. $15.8 \%, \mathrm{p}=0.02)$. Conclusions: When age-adjusted cancer rates were taken into consideration, the esophageal cancer rate in young men and women was shown to be increased in Ağr1 province, contrary to Turkey's general. Despite an increase in the crude incidence of gastric cancer, when adjusted to age, the incidence seems to be in accordance with the general tendency.

Keywords: Cancer, endoscopy, eastern Anatolia, the incidence
(iD) Erkan Çağlar
(D) Kadir Balaban
(iD) Deniz Atasoy
(D) Aslı Sezgin Çağlar
D Abdurrahman Akay

ORCID IDs of the authors: E.C. 0000-0001-7246-0952 K.B. 0000-0000-0000-0011 D.A. $0000-0000-0000-0001$ A.S.C. $0000-0000-0000-0001$ A.A. $0000-0000-0000-0003$ 
Amaç: Gastrointestinal sisteme ait kanserler doğu Anadolu bölgesinde morbidite ve mortalitenin önemli sebeplerinden biridir. Bu kanserlerin bu bölgeye özgü yıllık insidansı ve klinik semptomları konusunda çok fazla bilgi bulunmamaktadır. Yöntem: Temmuz 2014-Ağustos 2015 tarihleri arasında yapılmı̨s olan endoskopik incelemeler ile bu incelemeler sırasında alınan biyopsi sonuçları retrospektif olarak değerlendirilmiştir. Yaş spesifik ve kaba insidanslar, o bölgenin valiliği tarafından bildirilen 2014 yılına ait nüfus sayısına göre hesaplanmıştır.

Bulgular: 12 aylık zaman diliminde $927(\% 78,8)$ üst ve $249(\% 21,2)$ alt gastrointestinal sisteme yönelik olmak üzere toplam 1176 endoskopik inceleme yapılmıştır. Bu endoskopik incelemeler sonucunda 14 (\%19,1) özofagus kanseri, 49 $(\% 67,1)$ mide kanseri, ve $10(\% 13,6)$ kolorektal kanser tanısı konulmuştur. Erkek ve kadınlar için sırası ile özofagus kanseri kaba insidans1 100 binde 2,4 ve 2,6; mide kanseri kaba insidans1 9,1 ve 8,3; kolorektal kanser kaba insidans1 ise 2,8 ve 0,7 olarak hesaplanmıştır. Cinsiyete göre yaşa uyarlanmış özofagus kanseri hızları 30-34 yaş grubu erkeklerde 100 binde 0,34 ve 40-44 yaş kadınlarda ise 100 binde 3,03 olarak bulunmuştur. Kilo kaybı üst gastrointestinal malignitesi olanlarda kolorektal malignitesi olanlarla karşılaştırıldığında anlamlı şekilde daha fazla iken (sırası ile \%49,2 vs. \%10, $\mathrm{p}<0,001$ ), anemi kolorektal malignitesi olanlarda üst gastrointestinal malignitesi olanlardan daha sık görülmekteydi (sıras1 ile $\% 90$ vs. $\% 15,8, \mathrm{p}=0,02)$.

Sonuç: Yaşa uyarlı kanser hızları göz önüne alındığında Türkiye genelinin aksine, Ağrı ilinde genç erkeklerde ve genç kadınlarda özofagus kanser sıklığı artmıştır. Mide kanserinin kaba insidansı her ne kadar yüksek saptanmış olsa da yaşa uyarlandığında insidansı genel eğilime benzerdir.

Anahtar sözcükler: Kanser, endoskopi, Doğu Anadolu, görülme siklığ 1

\section{INTRODUCTION}

Gastrointestinal malignancies are the leading cause of death in Turkey, like in the world. Having a decreasing incidence in the last decades, gastric cancer causes 738.000 deaths per year in the world ${ }^{1,2}$. The decrease in the frequency could be related to increased hygiene standards, improvement in the food preservation techniques, an increase in consumption of fresh vegetables and fruits, and decrease in Helicobacter pylori infection rate ${ }^{3}$. On the other hand, esophageal cancer causes 400.200 deaths per year in the world with increasing frequency of adenocarcinoma in the west and squamous carcinoma in the east ${ }^{4}$. Obesity in the west and alcohol and tobacco consumption in the east are responsible for the increased incidence.

A strong correlation is present between gastrointestinal malignancies and geographical distribution. In the eastern parts of Turkey, still, the incidences of upper gastrointestinal malignancies are high with small decreases in mortality rates reported. Colorectal malignancies are the $3^{\text {rd }}$ most prevalent malignancies diagnosed and the $2^{\text {nd }}$ leading cause of death due to oncologic reasons in the world ${ }^{5,6}$. Cultural, social, and environmental factors and genetic predispositions play a role in the differences of colorectal cancer incidences across different regions ${ }^{7}$. When similar age groups are considered, colorectal cancer incidence is 2-3 times higher in developed countries compared to underdeveloped countries. According to the data of Turkish Republic Ministry of Health, Cancer Control Department, the rate of colorectal cancers is higher than the rate of upper gastrointestinal diseases in our country ${ }^{8}$.
In this study, we aimed to investigate the upper gastrointestinal and colorectal malignancies in the Ağrn province of the northeastern part of Turkey.

\section{MATERIAL AND METHODS}

A total of 1176 endoscopic investigations between July 2014 and August 2015 were evaluated retrospectively. Upper gastrointestinal studies were done with an endoscope (EG-250; Fujinon, Tokyo Japan) and colonoscopic interventions were done with a colonoscope (EC-3885 TLK; Pentax Tokyo Japan). Endoscopic data was obtained from MedGate v4.0 image transfer system. All the procedures were performed by a single gastroenterologist (EC). Pathological evaluations were done by a single pathologist (KB). The tumor localization and histological types of biopsies of the esophagus, stomach, and colon were recorded. Pathological examination was performed from paraffin-embedded tissues with hematoxylin-eosin stain under a light microscope.

For the calculation of crude and sex and genderadjusted incidences, the mid-year population of Ağrı province of Turkey in 2014 provided by the Turkish Statistical Institute was taken into consideration. According to this, the total population, male population, and female population were $549.435,285.449$, and 263.986 , respectively ${ }^{9}$.

Statistical analysis was done with SPSS Version 18.0 software. For comparison of categorical variables, Ki-square and for comparison of noncategorical data, Student's-t test was utilized. P < 0.05 was considered statistically significant. 


\section{RESULTS}

Of the patients included in the study, 42 were male, and 31 were female. Gastric cancer was diagnosed in 49 , esophageal cancer in 14 , and colon cancer in 10 patients. The demographics and clinical features of the patients are presented in Table 1. The median age of patients was 62 years (range, 30-85). The incidence of esophageal cancer during endoscopy was $1.5 \%$ (14/927), of gastric cancer was $5.2 \%$ (49/927), and of colon cancer was 4.0\% (10/249). While the Hemoglobin level in patients with upper gastrointestinal cancers was $12.77 \pm 0.97 \mathrm{gr} / \mathrm{dl}$, the level in patients with colon cancer was $11.1 \pm 1.13$ $\mathrm{gr} / \mathrm{dl}(\mathrm{p}<0.001)$. Localizations and histopathological features of the cancers are shown in Table 2. Crude prevalence rates per 100.000 individuals for esophageal cancer was 2.4 in men and 2.6 in women, for gastric cancer was 9.1 in men and 8.2 in women, and for colon cancer was 2.8 in men and 0.7 in women (Table 3). Age-standardized rates of the diagnosed cancers for both sexes are presented in Table 4.

A gastrointestinal stromal tumor was diagnosed in in the proximal stomach in one male patient in this series.

\begin{tabular}{|c|c|c|}
\hline Age* & & Years $( \pm S D)$ \\
\hline & Patients with esophageal cancer & $61.73 \pm 15.22$ \\
\hline & Patients with gastric cancer & $63.22 \pm 11.79$ \\
\hline & Patients with colorectal cancer & $61.70 \pm 13.30$ \\
\hline \multirow[t]{4}{*}{ Sex $x^{\pi}$} & & $M / F$ \\
\hline & Patients with esophageal cancer & $7 / 7$ \\
\hline & Patients with gastric cancer & $27 / 22$ \\
\hline & Patients with colorectal cancer & $8 / 2$ \\
\hline \multicolumn{2}{|c|}{ Symptoms } & $n(\%)$ \\
\hline & Anemia (in all patients) & $19 / 73(26 \%)^{\beta}$ \\
\hline & Weight loss (in all patients) & $23 / 73(43.8 \%)^{\mu}$ \\
\hline & Dysphagia (in patients with upper GI malignancy) & $37 / 63(58.7 \%)$ \\
\hline & Hematemesis (in patients with upper GI malignancy) & $6 / 63(9.5 \%)$ \\
\hline & Epigastric pain (in patients with upper GI malignancy) & $9 / 63(14.3 \%)$ \\
\hline & Nausea/Vomiting (in patients with upper GI malignancy) & $6 / 63(9.5 \%)$ \\
\hline & Rectal hemorrhage (in patients with colorectal malignancy) & $6 / 10(60 \%)$ \\
\hline
\end{tabular}

SD: standard deviation, M: male, F: female, GI: gastrointestinal

* The difference between ages according to cancer types was not statistically significant $(\mathrm{p}>0.05)$.

ๆ The gender distribution was not statistically significant among different cancer types $(\mathrm{p}>0.05)$.

${ }^{\beta}$ Hemoglobin levels below $13 \mathrm{gr} / \mathrm{dl}$ in men and below $12 \mathrm{gr} / \mathrm{dl}$ in women were considered as anemia. Anemia was statistically significantly more common in colorectal malignancies than upper gastrointestinal malignancies $(9$ vs 10 , respectively, $\mathrm{p}<0.001)$

${ }^{\mu}$ Weight loss was statistically significantly more common in upper gastrointestinal malignancies than colorectal malignancies $(31$ vs 1 , respectively, $\mathrm{p}=0.02$ ). 
Table 2: Cancer characteristics

Esophageal cancer 14

Localization

Mid esophageal

Low esophageal

$12(85.7 \%)$

$2(14.3 \%)$

Histopathological type

Squamous cell

$13(92.8 \%)$

Adenocarcinoma

$1(7.2 \%)$

Gastric cancer

49

Localization

Cardia

$25(51 \%)$

Corpus

$15(30.6 \%)$

Antro-piloric

Linitis plastica

Histopathological type

$7(14.2 \%)$

$2(4 \%)$

Adenocarcinoma

$39(79.5 \%)$

Intramucosal adenocarcinoma

$6(12.2 \%)$

Signet ring cell adenocarcinoma

$3(6.12 \%)$

Gastrointestinal stromal cell tumor

$1(2.04 \%)$

Colorectal cancer

10

Localization

Descending colon

$1(10 \%)$

Sigmoid colon

$6(60 \%)$

Rectum

$3(30 \%)$

Histopathological type

$10(100 \%)$

Adenocarcinoma

Table 3: Sex-adjusted incidence rates per 100.000 individuals for esophageal, gastric, and colorectal cancers in this study compared with Turkey's general

\begin{tabular}{llccc}
\hline \multirow{2}{*}{ Turkey* } & & Esophageal cancer & Gastric cancer & Colorectal cancer \\
& Male & 2.0 & 5.9 & 9.3 \\
\multirow{2}{*}{ In our series } & Female & 1.2 & 3.9 & 8.0 \\
& & & & \\
& Male & 2.4 & 9.1 & 2.8 \\
& Female & 2.6 & 8.3 & 0.7 \\
\hline
\end{tabular}

* Dataset records of 2014 of Republic of Turkey Ministry of Health, General Directorate of Public Health, Cancer Control Department

"According to the Turkish Statistical Institute data for 2014, the total mid-year population of Ağr1 province was 549.435 with 285.449 men and 263.986 women. 
Table 4: Age-standardized cancer incidences per 100.000 individuals for both sexes

$\begin{array}{lllllllllllll}\text { Age groups } & 30-34 & 35-39 & 40-44 & 45-49 & 50-54 & 55-59 & 60-64 & 65-69 & 70-74 & 75-79 & 80-84 & 85-89\end{array}$

\section{Esophageal cancer}

Turkey"

In our series

$\begin{array}{ll}\text { M } & 0.1 \\ \text { F } & 0.2\end{array}$

0.5

$\begin{array}{ll}1.2 & 2.6 \\ 0.7 & 1.8\end{array}$

$\begin{array}{cccccccc}3.5 & 6.3 & 7.9 & 11.0 & 12.1 & 21.6 & 19.1 & 14.1 \\ 1.7 & 2.5 & 4.4 & 4.5 & 6.9 & 7.6 & 10.9 & 8.2 \\ 0 & 0 & 0.7 & 0.35 & 0.35 & 0.7 & 0 & 0 \\ 1.2 & 0.6 & 0.33 & 0 & 0 & 0.36 & 0.35 & 0\end{array}$

\section{Gastric cancer}

$\begin{array}{lcccccccccccccc}\text { Turkey" } & \mathrm{M} & 2.2 & 3.7 & 7.7 & 15.1 & 26.0 & 40.6 & 63.4 & 79.1 & 108.6 & 132.1 & 129.3 & 105.1 \\ & \mathrm{~F} & 1.8 & 2.9 & 5.5 & 8.5 & 11.4 & 15.8 & 22.5 & 32.5 & 52.1 & 54.0 & 56.0 & 64.7 \\ \text { In our series } & \mathrm{M} & 0.34 & 0 & 0.34 & 0.95 & 0.31 & 1.2 & 1.7 & 0.53 & 1.5 & 0.9 & 0.34 & 0.34 \\ & \mathrm{~F} & 0 & 0 & 0 & 0.26 & 1.38 & 1.23 & 1.01 & 1.48 & 0.37 & 1.45 & 0 & 0.29 \\ \text { Colorectal cancer } & & & & & & & & & & & & & \\ \text { Turkey" } & \mathrm{M} & 2.2 & 4.1 & 7.8 & 12.8 & 21.6 & 35.0 & 61.6 & 84.7 & 110.6 & 123.9 & 138.4 & 130.2 \\ & \mathrm{~F} & 2.2 & 4.6 & 4.9 & 10.2 & 15.9 & 27.2 & 39.9 & 43.8 & 58.1 & 80.7 & 75.4 & 65.4 \\ \text { In our series } & \mathrm{M} & 0 & 0.28 & 0 & 0 & 0.31 & 0.30 & 0 & 0.8 & 0 & 0.3 & 0.34 & 0 \\ & \mathrm{~F} & 0 & 0 & 0 & 0.26 & 0 & 0 & 0.33 & 0 & 0 & 0 & 0\end{array}$

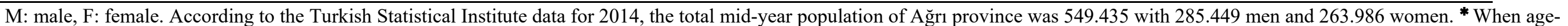

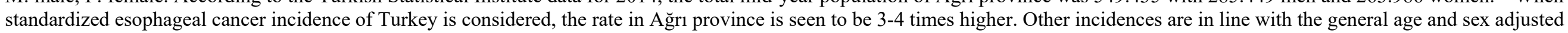
incidences of Turkey. ${ }^{\top}$ Cancer records for 2014 of Republic of Turkey Ministry of Health, General Directorate of Public Health, Cancer Control Department
} 


\section{DISCUSSION}

Gastric and esophageal cancer incidences are high in eastern Turkey. Asian upper gastrointestinal cancer (gastric and esophageal) zone starts from far east passing through middle Asia, including the eastern parts of Turkey is directed towards the middle east. In this study, crude incidences for gastric and esophageal cancers in Ağr1 province were higher than average frequencies of Turkey for both sexes. However, when cancer rates were adjusted to age, only the rate of esophageal cancer was seen to be 3-4 times greater than the average. The gastric cancer rate is decreasing in the world. Reasons for this decrease could be diet factors and improvement in food preservation techniques. However, it is still prevalent in developing countries and in low socioeconomic populations of the developed countries. According to the data of Turkish National Cancer Control Department, gastric cancer incidence per 100.000 individuals was 5.9 for men and 3.9 for women ${ }^{8}$. In our series, crude frequencies for both sexes were 2-2.5 times higher than general of country (see Table 3). When adjusted to age, we didn't encounter any increase in the rates (see Table 4). In a city of Van, socioeconomically and geographically very similar to Ağrı province, Turkdogan et al. reported a gastric or esophageal cancer in every 7 endoscopic interventions ${ }^{10}$. Binici et al., from Erzurum region, said that low fresh vegetable consumption, use of boiled butter, burning manure for bread baking, and absence of refrigerator use could be responsible for this high incidence of upper gastrointestinal malignancies in this region ${ }^{11}$. Helicobacter pylori infection rate in the gastric cancer patients from this region, a significant pathogen in gastric carcinogenesis, was reported to be similar to the control group ${ }^{10}$. Thus, other than Helicobacter pylori, different factors, especially food preparation techniques, should be blamed in gastric cancer pathogenesis in this region.

Previous studies reported high incidences of esophageal cancer in the eastern parts of Turkey. Coskun et al., from Hakkari province, socioeconomically, and geographically very similar to Ağrl, reported esophageal cancer incidence of 8.8 for men and 7.2 for women ${ }^{12}$. In this study, the crude rates for esophageal cancer were 2.6 for men and 2.4 for women and were slightly higher than country average, but were very low compared to Hakkari. We saw that when esophageal cancer rates were adjusted to age, in men of 30-34 years of age the rate was 3 times higher than Turkey's average rate and in women of 40-44 years of age the rate was 4 times higher than the average (see table 4). Likewise, from similar province of Van, Topcu et al., reported that esophageal cancer was the diagnosis in every 5 cancers in this region ${ }^{13}$. Possible etiological factors were low socioeconomic status, tobacco and alcohol consumption, and abundant amounts of nitrous compounds in the diet. A special technique of 'kitlama' while drinking hot tea in this region, was speculated as an etiologic agent, Binici et al., reported that this factor was not that important, relieving tea drinkers ${ }^{11}$. In our study, in accordance with the other reviews from this region, we saw that the predominant histological type was squamous cell cancer (92.8\%). In Europe and USA, both overall and squamous cell cancer rates decrease markedly. However, incidences of adenocarcinoma under Barrett's ground are reported to increase ${ }^{14,15}$. Squamous cell cancer is still seen with high rates especially in Asia, Africa, and South America ${ }^{16}$. Both high altitude and low socioeconomic status could be the reasons for the high esophageal cancer rates in this region which is in the west edge of the Asian upper gastrointestinal cancer zone, compared to the rest of the regions of the country.

In this study, colon cancer incidence was seen to be lower than both esophageal and gastric cancer incidences. The region is different from the general of Turkey regarding colon cancer incidence. According to the data of the Cancer Control Department of Ministry of Health, colon cancer is the $3^{\text {rd }}$ most common malignancy in Turkey, and male/female ratio is close to $1^{8}$. In the region of Ağrı, this rate is nearly 4 times lower than Turkey's average, and male/female ratio is $4 / 1$ (see Table 3). In addition, in our series, almost all colorectal cancers were located in distal colon and rectum. Aykan et al. reported that in Turkey, $68.4 \%$ of the colorectal cancers were located in the colon (more than half in proximal colon) and $31.6 \%$ in the rectum ${ }^{17}$. In the same study, only $4.1 \%$ of the colorectal cancers were from eastern Anatolian region. Genetic and environmental factors together with lifestyle differences (red meat consumption, tobacco use, etc.) could be responsible for these regional differences. In addition, geographical obstacles in front of the Health Ministry's Colorectal Carcinoma Screening Program in the eastern regions should be appropriately investigated, and people should be encouraged for active participation.

When symptoms were to be considered, the anemia rate was higher in colorectal malignancies, and weight loss rate was higher in upper gastrointestinal malignancies $(\mathrm{p}<0.001$ and $\mathrm{p}=0.02$, respectively).

In this study, crude incidences of the upper gastrointestinal malignancies were higher than Turkey's incidences. However, except esophageal cancer rate in younger individuals, age-adjusted cancer rates were lower than Turkey's averages. The reason for this could be the difference in the demographics of the Ağr1 province population from Turkey's general, especially regarding 0-30 years of age group. The high number of people in this age group decreased the percentages of the age groups of older than 30 years, thus during calculations decreased the rates of age-adjusted incidences. 
Although retrospective, this study has some strengths. All the endoscopic interventions were performed by the same gastroenterologist in a single endoscopy center in the Ağrı province and pathologic evaluations were done by the same and single pathologist in the region. The incidence values presented in this study could be the lowest possible numbers for this region because people living in the periphery of this province could have been admitted to the neighboring areas for endoscopic evaluations.

As a result, according to the results of this study, esophageal cancer incidence in Ağr1 province is increased both in young males and females compared to Turkey's average. Regarding the crude occurrences, upper gastrointestinal malignancy rate is higher than colorectal malignancy rate, and this trend is opposite to Turkey's general. Modifying the screening programs according to these regions could be the first approach to reduce the mortality and morbidity rates of the upper gastrointestinal malignancies in the area.

\section{REFERENCES}

1. Wright NA, Poulsom R, Stamp G, et al. Trefoil peptide gene expression in gastrointestinal epithelial cells in inflammatory bowel disease. Gastroenterology, 1993;104:12-20.

2. Jemal A, Bray F, Center MM, et al. Global cancer statistics. CA Cancer J Clin 2011;6:69-90.

3. Sitarz R, Skierucha M, Mielko J, et al. Gastric cancer: epidemiology, prevention, classification, and treatment. Cancer Manag Res 2018;10:239-248.

4. Wheeler JB, Reed CE. Epidemiology of esophageal cancer. The Surgical Clinics of North America 2012; 92:1077-87.

5. GLOBOCAN. Estimated number of colorectal cancer new cases in 2018, worldwide, both sexes, all ages Cancer Today 2018 [cited 2018 October,19, 2018]; Available from: https://gco.iarc.fr/today/ onlineanalysis table? $\mathrm{v}=2018 \quad$ \&mode= cancer\&mode_population $=$

continents \&population $=900 \&$ populations $=900 \& \mathrm{key}=\mathrm{a}$ sr\&sex $=0 \&$ cancer $=39 \&$ type $=0 \&$ statistic $=5 \&$ prevalenc $\mathrm{e}=0 \&$ population_group $=0 \&$ ages_group $\% 5 \mathrm{~B} \% 5 \mathrm{D}=0 \&$ ages_group $\% 5 \mathrm{~B} \% 5 \mathrm{D}=$

$17 \& \mathrm{nb}$ items $=5 \&$ group_cancer $=1 \&$ include_nmsc $=1 \&$ include_nmsc_other $=1$.

6. Bray, F. , Ferlay, J. , Soerjomataram, I. , et al. Global cancer statistics 2018: GLOBOCAN estimates of incidence and mortality worldwide for 36 cancers in 185 countries. CA: A Cancer Journal for Clinicians 2018; 68: 394-424. doi:10.3322/caac. 21492
7. Boyle P, Longman JS. ABC of colrectal cancer: Epidemiology. BMJ 2000; 321: 805-8.

8. HSGM. Cancer Statistics of Turkey in 2014. https://hsgm.saglik.gov.tr/tr/kanser istatistikleri/yillar/495-2014-y\%C4\%B11\%C4\%B1-

$\mathrm{t} \% \mathrm{C} 3 \% \mathrm{BCrkiye}-k a n s e r-i s t a t i s t i k l e r i . h t m l$

9. İstatiksel Göstergeler/ Bölgesel İstatikler/ 2014 Nüfus ve Göç verileri. tuik.gov.tr/Start.do

10. Türkdogan MK, Akman $N$, Tuncer $I$, et al. Epidemiological aspects of endemic upper gastrointestinal cancers in eastern Turkey. Hepatogastroenterology 2005;52:496-500.

11. Binici DN, Koca T, Dursun H. Dietary Habits, demographical, and socio-economical risk factors of the newly diagnosed gastric cancers in the Eastern Anatolia Region of Turkey: an endemic upper gastrointestinal cancer region. Dig Dis Sci 2009;54:2629-33.

12. Suleyman C, Atakan Y, Ipek C, İsmail B, Ogun A. Annually Incidence of Esophagus Cancer in the Hakkari City of Eastern Anatolia. Journal of Gastroenterology and Hepatology Research 2013; 2: 696-698.

13. Topcu N, Ilhan M, Koca D, et al. Analysis of 3065 cancer cases in an Eastern part of Turkey: The results of hospital-based registries from Van Region. Annals of Oncology 2004; 15(Supplement 3): 560.

14. Corley DA and Buffler PA. Oesophageal and gastric cardia adenocarcinomas: analysis of regional variation using the cancer incidence in five continents database. International Journal of Epidemiology 2001; 30: 1415 1425.

15. Pera M, Manterola C, Vidal O, and Grande L. Epidemiology of esophageal adenocarcinoma. Journal of Surgical Oncology 2005; 92: 151-159.

16. Yousefi MS, Sharifi-Esfahani M, PourgholamAmiji N, et al. Esophageal cancer in the world: incidence, mortality and risk factors 2018; 5: 25042517.

17. Aykan NF, Yalçın S, Turhal NS, et al. Epidemiology of colorectal cancer in Turkey: A cross-sectional disease registry study (A Turkish Oncology Group trial). Turk J Gastroenterol 2015; 26: 145-53. 